\section{ADDITIONAL. RECORDS OF MEADOWLARK NIGHT SONG}

by Robert W. Nero, Regina

In 1959 I reported a record of night song given by a Western Meadowlark (Sturnella neglecta) (Blue Jay, 17: 59). Since then I have heard a meadowlark sing at night on two occasions. A single brief song was heard in 1961 on May 25 at 10:30 p.m., and on June 4 at 10:40 p.m. (M.D.T.). Both songs were apparently given in response to our car as we passed slowly along a field road searching for mice about eight miles east of Regina. Since the song was heard in about the same place each time I presume that it was given by the same territorial bird. On each occasion we re-traced our route at least once but the song was only heard on our first passage. Although I have driven many miles at night in similar situations I have no other record of night song in this species. Night song was not recorded for any diurnal species during the course of a study in Wisconsin by Aldo Leopold and Alfred E. Eynon (1961. Avian daybreak and evening song in relation to time and light intensity. Condor, 63: 269-293).

\section{INFORMATION WANTED RE: HORNED GREBE}

Victor Schmidt of Melville is study ing the life history of the Horned Grebe and would appreciate receiving information from other Saskatchewan observers re: spring and fall migration, nest records, etc. Victor is also interested in other migration records from various parts of Saskatchewan; perhaps other young naturalists would like to compare notes with Victor. We also remind him to watch for the Co-operative Spring Migration reports in the September issue of the Blue Jay.

\title{
Plants
}

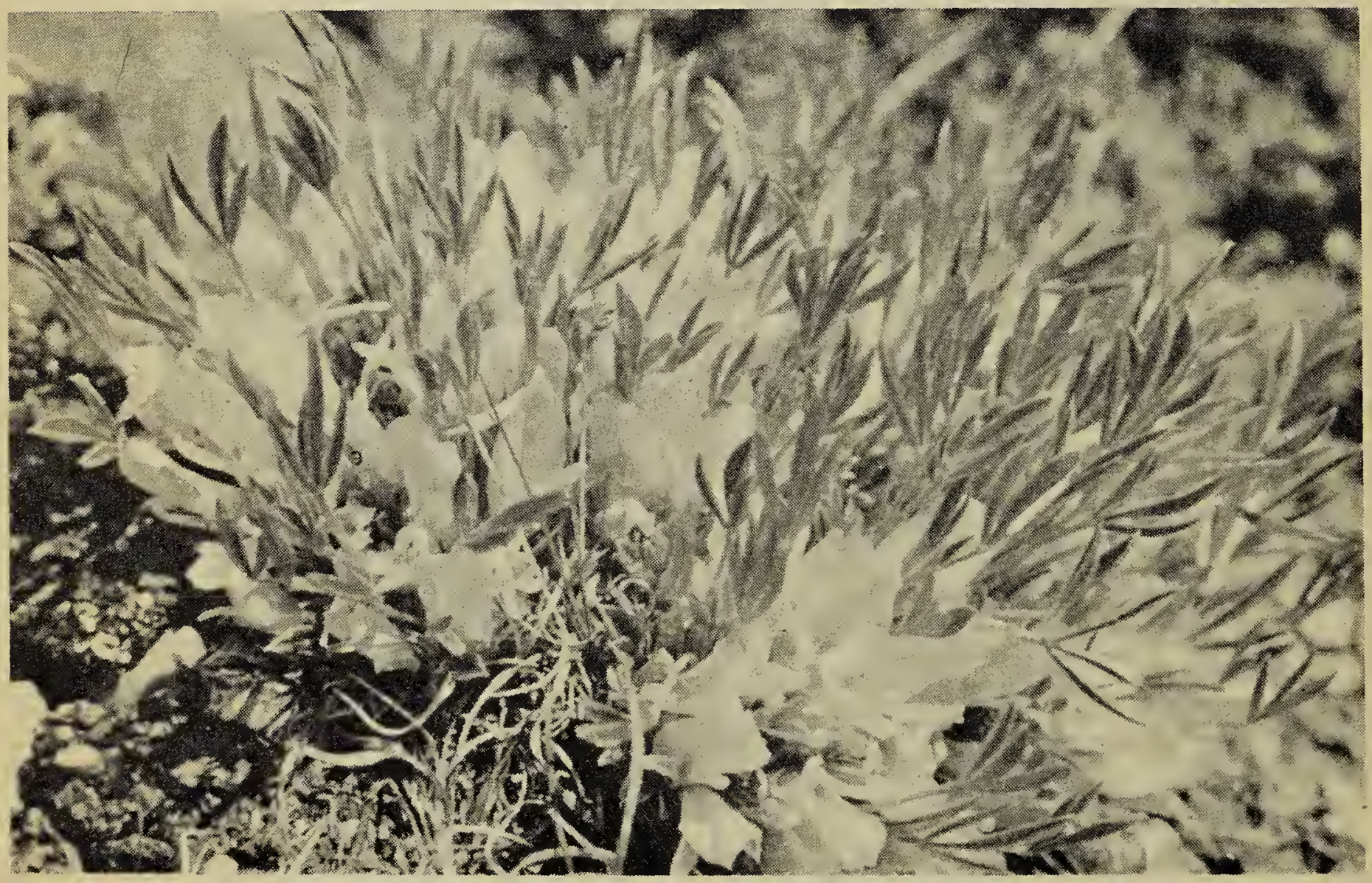

Photo by G. F. Ledingham

Astragalus gilviflorus Sheld.

This early-flowering legume is one of the Astragalus species being studied by our Editor. As the Blue Jay goes to press, the cushion milk-vetch shown here is coming into bloom, and Dr. Ledingham is collecting other species of Astragalus in the southwestern United States. Readers who know the Editor as a careful observer and keen naturalist will be looking forward to hearing about his trip. 